\title{
A SYNTACTICAL PATTERN OF 2.5 YEARS OLD BOY UTTERANCE (A CASE STUDY)
}

\author{
Akhmad Hairul Umam \\ School of Management \& Leadership, Tanri Abeng University \\ ahmad.umam@tau.ac.id
}

\begin{abstract}
This study aims to identify the utterances and to explore the language acquisition for 2.5 years old boy in its syntactical pattern. The duration of this research is four months by observing and recording the words expression pronounced by the boy. Based on the finding, this boy firmly acquires the language mostly by nature (innate ability). However, the positive environment enables him to develop the child's language fluency. Both nature and environment have important roles in the child language acquisition. It is in line with the theoretical frame work of language acquisition that in general language acquisition is shaped and influenced mainly by two factors: biological (innate ability) and environmental factors. Awhile the type of the utterances spoken by the boy aged 2.5 years old consisting of declarative $48 \%$, interrogative $29 \%$, imperative $21 \%$, and exclamation utterances $2 \%$. In the syntactical pattern, the boy mostly speaks using the predicate utterances pattern $(P)$, subject-predicate $(S-P)$, then predicate-subject $(P-S)$. The predicate $(P)$ and subject-predicate $(S-P)$ pattern of utterances are the most frequently spoken by boy. The boy is accustomed to and easily expresses his intentions with those two patterns that have represented a complete utterance according to what the boy intended.
\end{abstract}

Keywords: Language acquisition, syntactical pattern, stages of language acquisition.

\section{INTRODUCTION}

Investigating the language acquisition is very interesting and it can be longitudinal study. Language is inseparable with human. As human being, people use language to communicate or interact with each other mostly happen without thinking. According to (Clark, 1977) language is a basic ingredient in virtually every social situation. Language maintains social relationships among people since by using language, people can communicate and share information or messages to social members. Therefore, language has a main role in human affairs. How children learn and use language in daily life is a fascinating matter to be explored all the time not only by linguists but also their parents. For instance, the way a child constructs un utterance always makes everyone around him/her very curious. In this case, the researcher is very keen to observe a child in acquiring the language. This research will concern with the production of utterances as uttered by a boy and the language pattern which are reflected in the utterances. 
Observing the language growth for a child, mostly parents take it for granted that language will emerge in their developing child. Typically developing children pass through similar stages and in a short time become adult speakers of their local language or languages. Usually children babble, pass through a single and multiword stage, and then start to produce entire utterances that increase in complexity (Thorton, 2016). If we look to the function of language itself, according to (Leech, 1974) there are five functions of language: informational, expressive, directive, aesthetic, and phatic. However, in this study the researcher will focus only to the utterances and its syntactical spoken by 2.5 years old boy as formulated into 4 types; declarative (making a statement), interrogative (asking a question), imperative (giving a command or making a request), and exclamatory (expressing a strong feeling).

It goes without saying that around the age of two years, normally the children's vocabulary begins to expand rather rapidly, and their syntactic repertoire consists of simple two-word or even more than two-word sentences, i.e. three-word utterances or more-thanthree-word utterances. In addition, sometimes the children utter one word to represent a complete thought. Their utterances are produced very definitely and they are an unstructured combination of words; however, they are very meaningful. They can represent what the children want to do or convey. Therefore, the objective of this study tries to identify the utterances and to explore the child's language acquisition in its syntactical pattern.

As cited in (Meniado, 2016) there are many linguists attempting to explain such humanly overwhelming of language acquisition. Lenneberg, Chomsky, and McNeill (in Brown, 2007) for example, share common belief that language is a "specie-specific" behavior and that it is innate in every individual. However, other linguists like Bloomfield, Skinner, Fries, Hymes, Halliday, and Oller (in Brown, 2007), believe that language is acquired behavior through conditioning and reinforcement and that it is best learned through interaction in various situations and applications. Based on these opposing views, clearly understood that language acquisition is influenced and controlled by two powerful factors heredity (nature) and environment (nurture). 
Anglo-Saxon : Jurnal Ilmiah Program Studi Pendidikan Bahasa Inggris

Vol. 11, No 1: 13- 23

Juni 2020

P-ISSN 2301-5292

E-ISSN 2598-9995

In addition to this topic how human acquires the language, Linguists have different views with the question how is first language (L1) learned or acquired? / Does human acquire a language biologically or through an input and the environment? To answer this question, the Behaviorist/ Empiricist Theory such as Leonard Bloomfield, B. F. Skinner, and Charles Fries argues logically that language is acquired behavior through conditioning and reinforcement. On this theory, children acquire language from the conditioning and reinforcement of their environment which involve family members, peers, teachers, and the society as a whole. Further, it's understood and believed that language learning is the result of imitation, practice, feedback on success, and habit formation (Brown, 2000).

Awhile the Rationalist/Cognitivist/Mentalistic Theory of Noam Chomsky, on the other hand, believes that language is principally cognitive, mental process, and rule-governed (universal grammar) both in deep and surface structures. This theory states that man has a Language Acquisition Device (LAD) that enables him to learn a language in a natural way. Functional Theory/Interactionist Model in other literatures claim that language development goes along with the dynamic interaction of cognitive development and the environment (Brown, 2007). This means that interaction or communication with adults within the child's cognitive capacities provide rich inputs that can contribute to language development.

However, (Pine, 1995) investigated that infants understand their first word as young as 5 months, produce their first words between 10 and 15 months of age, reach the 50 -word milestone in producing vocabularies around 18 months of age, and the 100-word milestone between 20 and 21 months. Soon after that, the vocabulary development of children continues rapidly that tracking how many words the children know becomes unwieldy. In addition, the vocabulary size of an average 6-year-old according to (Templin, 1957) has been estimated at 14,000 words.

In linguistics, there are a few terms often used in language acquisition when a child starts learning to speak for first time such mother tongue, native speaker, and first language. Basically, three of them are synonyms and used interchangeably. In Merriam Webster stated that mother tongue is the language that a person learns to speak first. Awhile Longman dictionary defines mother tongue as the first and main language that you learnt when you 
were a child. Slightly similar to both definition also found in the Internet Encyclopaedia: in a monolingual society, 'mother tongue' means the first language acquisition that usually takes place within the family.

Interestingly, the researcher found in (Twerefou, 2015) the 'father tongue' is also used as the mother tongue of the father and 'mother tongue' as the mother tongue of the mother of the multilingual family. According to her stating that both mother and father tongues carry the same emotional value and rank. From these definitions we can imply that mother tongue means the first language acquisition that usually takes place within the family. Other say that the mother tongue is the language that is already heard by the foetus in his mother's womb, then it is learnt by the baby from his mother through complicated brain-processes.

To avoid misunderstanding toward the terms used in this study, the researcher defines two terms applied in this research study. They are syntactic pattern or structure (Bussmann, 1996) sequence of linguistic elements formed by segmentation which can consist of sound, words, phrases, clauses, or entire sentences. The function of language (Clark, 1977) is intimately bound up with the speakers' and listeners' mental activities during communication, in particular with the speakers' intentions, the ideas speakers want to convey, and the listeners' current knowledge.

\section{METHODOLOGY}

\section{Research Design}

The research study uses qualitative approach with a case study method in which the data collected through observation and interview for four months started from 14 August to 14 November 2019. This research is not to test a particular hypothesis but to describe a symptom of a child in producing the utterances (Umam, 2018). In addition, a case study is an in-depth study of a particular situation rather than a sweeping statistical survey. The method is used to narrow down a very broad field of research into one easily researchable topic (Shuttleworth, 2008). The researcher analysed one child as a case study to find out the kinds of utterances and the syntactic patterns that were produced in the subject's one-word utterances, two-word utterances, three-word utterances, and more-than-three-word utterances. 


\section{Data Gathering Procedure}

The researcher mainly gathered the data through observations and interaction. The researcher observed how a child with his father, mother, grandmother and grandfather as well as his friends-his nature and behaviors in communicating using verbal and non-verbal modes. The researcher fully understands the way how the boy communicates using his facial expressions, tone, voice, etc. During observations, the boy's responses were noted and included in the analysis based on the theories and principles of language acquisition. The data of this study which was collected with a tape recorder was transcribed and analyzed under the parameters of kinds of utterances and syntactic patterns in the subject's one-word utterances, two-word utterances, three-word utterances, and more-than-three-word utterances. The researcher intentionally observed and recorded the subject that produced sounds, words, and utterances for four months.

\section{Subject of the Study}

The subject of this case study is named Afkar Alkhalifi. He is two years and five months old born to a mixed family (Madurese \& Javanese) in South Tangerang Banten. He is the first child of a young couple considered as educated family by looking to the education background. He has a brother who is in the babyhood and infancy stages. His father is an English lecturer while his mother is a lecturer in informatic engineering. A physically, mentally, and socially healthy boy, he loves playing toy, running inside the house, watching YouTube videos, and touching every strange thing he sees. Still on his way of acquiring his first language, he always tries to ask his mother/father and grandfather/mother the names of things, actions, or ideas he observes inside and outside the house. He is mainly exposed to an environment where Indonesian language is spoken and written.

As the son of educated family, Afkar is always around whenever his parents, playing around with his toys, disturbing his father or mother, and talking to him/her whenever he pleases. He speaks Indonesian, but it is surprising in his 2 years and 5 months old he can speak fluency Indonesian words and answer some basic questions like 'Siapa namamu?' 'Berapa umurmu?' 'Di mana ayahmu?' 'Siapa nama adiknya'?' For that facts, at his age he can communicate fluency in Indonesian language. According to his mother, the language skill 
Anglo-Saxon : Jurnal Ilmiah Program Studi Pendidikan Bahasa Inggris Vol. 11, No 1: 13- 23 Juni 2020

P-ISSN 2301-5292

E-ISSN 2598-9995

of Afkar is very good with little grammatical errors. He is very lovely, friendly, and inquisitive child. He also displays strong characteristics in acquiring the language.

\section{FINDINGS AND DISCUSSION}

Based on data that has been collected in this study, in general the researcher found 175 data which are classified into 4 types of utterances. They are declarative, interrogative, imperative, and exclamation utterances. The percentage of the data can be seen in the following figure 1.

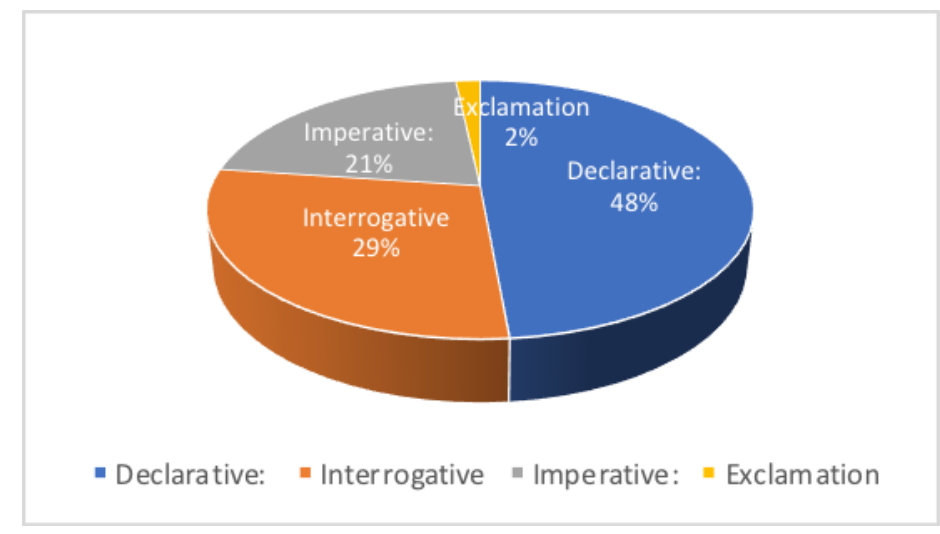

Figure 1. Percentage of Utterance

In the syntactical pattern, the data above can be classified into different forms. They are (1) The subject pattern (S) is 2 utterances, (2) The predicate pattern $(\mathrm{P})$ is 83 utterances. (3) The adverb pattern (A) found in 21 utterances. (4) Subject-predicate pattern (S-P) found in 38 utterances. (5) The predicate-subject (P-S) pattern found in 37 utterances. (5) Objectpredicate pattern (P-O) found in 20 utterances. (6) The predicate-object pattern (P-A) found in 20 utterances. (7) The predicate-adverb pattern (P-A) found in 19 utterances. (8) Adverbpredicate pattern (P-A) found in 5 utterances. (9) The subject-predicate-object- pattern (P-OA) found in 2 utterances. (10) Pattern of subject-predicate-adverb (S-P-A) found in 10 utterances. The summary and example of the pattern can be seen in the following table 1 .

Table 1. Syntactic Pattern

\begin{tabular}{l|c|r|r}
\hline & $\begin{array}{c}\text { Utterances based } \\
\text { on Syntactic Pattern }\end{array}$ & \multicolumn{1}{|l}{ olume } & Example of Utterances \\
\hline & Subject & 2 & Mainan kakak Ayah \\
\hline
\end{tabular}




\begin{tabular}{|c|c|c|c|}
\hline & & & $\mathrm{S}$ \\
\hline & Predicate & 36 & $\frac{\text { Udah diminum }}{\mathrm{P}}$ \\
\hline & Adverb & 12 & $\frac{\text { Ke rumah Afanafan }}{\mathrm{A}}$ \\
\hline & Subject-Predicate & $4^{2}$ & $\begin{array}{l}\text { Ayah lagi belajar } \\
\mathrm{S}\end{array}$ \\
\hline & Predicate-Subject & $\begin{array}{ll} & 1 \\
7\end{array}$ & $\frac{\text { Keluar bunda }}{\mathrm{P} \quad \mathrm{S}}$ \\
\hline & Predicate-Object & $\begin{array}{ll} & 1 \\
0 & \\
\end{array}$ & $\frac{\text { Beli susu kakak ya? }}{\mathrm{P} \quad \mathrm{O}}$ \\
\hline & Predicate-Adverb & $1 \quad 1$ & $\frac{\text { Pergi sana }}{\mathrm{P} \quad \mathrm{A}}$ \\
\hline & Adverb-Predicate & 5 & $\frac{\text { Bentar lihat }}{\mathrm{A} \quad \mathrm{P}}$ \\
\hline & $\begin{array}{l}\text { Subject-Predicate- } \\
\text { Object }\end{array}$ & 2 & Bunda lihat $\frac{\text { kakak pake helm }}{\mathrm{S} \quad \mathrm{P} \quad \mathrm{O}}$ \\
\hline 0 & $\begin{array}{l}\text { Subject-Predicate- } \\
\text { Adverb }\end{array}$ & $0^{1}$ & $\frac{\text { Kakak simpan situ }}{\mathrm{S} \quad \mathrm{P} \quad \mathrm{A}}$ \\
\hline
\end{tabular}

Looking to the data table 1 above, the findings show that the declarative utterance is the most widely spoken by the boy aged 2.5 years old named Afkar Alkalifi as many as 85 utterances, then interrogative utterance as many as 50 utterances. After that followed consecutively by imperative utterance with 37 utterances and exclamation with 3 utterances. Based on the observation, this happens because the boy more often expresses what he experiences and feels rather than expresses the interrogative and imperative sentences. In addition, mostly the boy is more accustomed to conveying or telling what happens to people around him instead of asking questions, ordering something, or conveying admiration to those around him.

The research will show for each type related to the situation how the utterance was produced by the boy. First, the declarative found in 85 utterances for example 'Azka nangis'. The utterance is produced when he sees his younger brother is crying. The purpose of the utterance is that the child tells his parents that his brother named Azka is crying and in need to get a help. The utterance shows that the boy can speak the utterance well by seeing the ongoing event. 
Second, the interrogative found in 50 utterances including interrogative sentences asking for something that happened in 30 utterances for example 'Ayah sholat masjid?' This kind of utterances uttered by the boy when he sees his father preparing to perform a Friday prayer normally conducted in Mosque. The meaning of the word of masjid in this sentence is a place for performing prayer. The interrogative sentence asking for people is found in 3 utterances such as 'mobil siapa?' The utterance is produced by the boy when he sees a car in front of his house is being parked. At that time the boy asked his grandmother whose car? And then his grandmother slowly answered 'Ini mobil om Ali'.

Furthermore, the researcher also found 7 utterances asking for a place for example 'Mana mainan Afkar?'. The statement occurred when the boy asked for his father about his toy. At that time the boy immediately asking his father about his toy of cars. But his father did not answer the question from his son. Awhile the interrogative utterances asking for a reason found in 5 utterances for example 'Kenapa susunya tumpah? The purpose of the sentence is that the boy asks a reason why the milk is spilled. The interrogative sentence asking for the number is found in 5 utterances for example 'Ada berapa bolanya?' The utterance appears when the boy is playing basketball in the house with his father and at that time the boy asking his father about the basketball that the boy has. And his father answered 'one'.

Third, there are 52 utterances of imperative including imperative utterances of 45 utterances for example 'Ayah sholat sana, dekat pintu!' The utterance was said by the child when his father wanted to take the prayer cloth on the chair. Suddenly the child told his father to pray in the room. The purpose of the utterance is to tell his father to pray in a place close to the door, the door next to the room of his mother and father. In addition, the invitation/hope imperative utterances are also found in 9 utterances for example 'Simpan Affan!' The sentence was uttered by the boy when he was playing a toy with friend in front of the house. Then the boy immediately saying to Affan to put his toy on basket. The imperative utterance omits 1 utterance for example 'Buat seperti itu!' The utterance was said by the boy when he was playing with his grandmother in front of his house and drawing a picture. On the ground 
using a small piece of wood. The boy intended to make a star, but the grandmother said that it was not a star image and the child answered let it be like that!

Fourth, the exclamation found in 3 utterances. For example, 'Bunda ikan besar sekali, wow besar bunda!' The utterance shows the boy's astonishment at seeing good ornamental fish on television. The statement emerged when the boy saw a good ornamental fish on television so the boy felt surprised or shocked. The meaning of the utterance spoken by the boy is that the boy is surprised and shocked to see good ornamental fish on television. From the utterance of the boy, he does not expect an answer from his mother, but the boy only expresses a shocking feeling to see the fish.

Referring to the table 2 above it can be perceived that the utterances pattern which is more often spoken by the boy is the predicate utterances pattern $(\mathrm{P})$, followed by subjectpredicate $(\mathrm{S}-\mathrm{P})$, then predicate-subject $(\mathrm{P}-\mathrm{S})$. However, based on the findings show that only the predicate $(\mathrm{P})$ and subject-predicate $(\mathrm{S}-\mathrm{P})$ utterances are the most frequently spoken by the boy because he is accustomed to and easily expresses his intentions with those two patterns that have represented a complete utterance according to what the boy intended.

The process of language acquisition for a boy is dynamic and unitary phenomena. Based on the observation, how the boy acquires, develops, and uses the language also influenced by many factors such as the parent positive attitude toward the languages and the encouragement of their child to learn the parents' mother tongue. Their role in developing the language acquisition for a boy is very significant. Since parents are role-models for their children, both their language and their attitude play an important role. In addition, both input and context are very important that lead them to the ability acquisition for children to communicate. The positive environment has big impact in developing language acquisition of a child.

\section{CONCLUSION}

Observing the syntactical pattern of utterances from 2.5 years old boy, the researcher can state that language acquisition for a child is shaped and influenced by multiple factors. 
Anglo-Saxon : Jurnal Ilmiah Program Studi Pendidikan Bahasa Inggris

Vol. 11, No 1: 13- 23

Juni 2020

P-ISSN 2301-5292

E-ISSN 2598-9995

Though the ability to acquire the language seemed innate, its development and enhancement were further shaped by the environment. As matter of fact, environment of the boy is also considered as one of the most important factors that lead him in having a successful development of language acquisition. In addition, both linguistic and social aspects should be taken into consideration.

Looking to the big impact of the parents, families, and people around the boy that plays an important role in the process of acquiring the language, there are two recommendation as best learning from this research study. First, parents are expected to be able to spend and provide time to invite their children to talk. A good response from parents when their children are talking is important factor so that children can use adult sentences that are complete and clear. The articulation of children becomes clearer and the vocabulary increases as well. So that children can speak sentences like adult sentences. Second, the parents must always invite and guide the children to speak and convey their intent without any fear. This to improve the child's utterances which are varied to become clearer and easily understood. Finally, this study is intended to give a contribution for further observation dealing with child's language development.

\section{REFERENCES}

Brown, D. H. (2000). Principles of language learning \& teaching (4th ed). New York: Pearson Education.

Brown, D. H. (2007). Principles of language learning \& teaching (5th ed.). New York: Pearson Education.

Bussmann, H. (1996). Routledge dictionary of language and linguistics (G.P. Trauth, Ed., \& G.P. Trauth, Trans). London and New York: Routledge.

Clark, H. H. C. E. V. (1977). Psychology and language an introduction. New York: Harcourt Brace Jovanovich.

Leech, G. (1974). Semantics. Suffolk: Richard Clay (The Chaucer Press) Ltd.

Meniado, C. J. (2016). First language acquisition: A case study of a three-year old Lebanese child. Journal of Child Language Acquisition and Development, JCLAD 4(3), 98112 . 
Anglo-Saxon : Jurnal Ilmiah Program Studi Pendidikan Bahasa Inggris Vol. 11, No 1: 13- 23

Juni 2020

P-ISSN 2301-5292

E-ISSN 2598-9995

Pine, J. M. (1995). Variation in vocabulary development as a function of birth order. Child Development, 1, 272-281.

Shuttleworth, M. (2008). Case Study Research Design. Retrieved from www.experimentresources.com/case-study-researchdesign.html

Templin, M. (1957). Certain language skills in children, their development and interrelationships. Minneapolis, MN: University of Minnesota Press.

Thorton, R. (2016). Children's acquisition of syntactic knowledge. USA: Oxford University Press.

Twerefou, I. C. (2015). Language acquisition and the dynamics of language use in a multilingual context.

Umam, A. H. (2018). Cross Cultural Adaptation \& Communication Behavior Regional Student of Tanri Abeng University. Progressive, XIII(1), 23-34. 